\title{
COMMUNICATION STRATEGY FOR WOMEN ORGANIZATIONS IN MINIMIZING FEMALE VIOLENCE DURING PANDEMIC
}

\author{
Dzikrina Aqsha Mahardika \\ Diponegoro University Semarang, Indonesia \\ dzirinaaqshamahardika@gmail.com
}

\begin{abstract}
The emergence of pandemic Covid-19 which struck many countries reveals a veil from the viewpoint of the women's world. Besides women are easily infected with Covid-19, apparently women are also prone to violence because of their pandemic. This research used qualitative descriptive research. The research concentrate on communication strategies and used Ledinghem \& Burning's theory of Relationship Management Theory. The research also took samples of women's organizations that concentrate on dealing with cases of violence against women who are Legal Resource Center for Justice Gender and Human Rights (LRC-KJHAM) Central Java province. Researchers were looking for data from primary and secondary sources. Data collection techniques of this study were interview techniques and documentation. The results of this research was to know the strategy of communication implemented by LRJ-KJHAM in minimizing the occurrence of women violence in the pandemic is known as the Central Java region. The research also shows that the Relationship Management Theory was applied by the LRC-KJHAM manager so that the women remain protected from violence despite the health protocol when the Covid-19 runs strictly.
\end{abstract}

Keywords: Communication; Women; Violence; Pandemic.

\begin{abstract}
Abstrak
Kemunculan pandemik Covid-19 yang melanda banyak negara mengungkap sebuah tabir kegelapan dari sudut pandang dunia perempuan. Selain perempuan mudah terpapar Covid-19, ternyata perempuan rentan mendapatkan kekerasan karena pandemik. Penelitian ini menggunakan pendekatan kualitatif deskriptif dan terkosentrasi pada strategi komunikasi dengan menggunakan teorinya Ledinghem dan Burning yakni Relationship Management Theory. Mengambil
\end{abstract}


sampel organisasi perempuan yang berkonsentrasi menangani kasus kekerasan terhadap perempuan yaitu Legal Recource Center untuk Keadilan Gender dan Hak Asasi Manusaia (LRC KJHAM) Provinsi Jawa Tengah. Teknik pengumpulan data menerapkan teknik wawancara serta dokumentasi. Hasil penelitian ini mengetahui strategi komunikasi yang diterapkan oleh LRJ KJHAM dalam meminimalisir terjadinya kekerasan perempuan dimasa pandemik. Penelitian ini juga menunjukkan bahwasanya Relationship management Theory diaplikasikan oleh pengurus LRC KJHAM agar para perempuan tetap terlindungi dari kekerasan meski protokol kesehatan Covid-19 dengan ketat.

Kata Kunci: Komunikasi; Perempuan; Kekerasan; Pandemik.

Accepted : April 21, 2020 Reviewed: May 6, 2020 Published: June 1, 2020

\section{Introduction}

The spread of coronavirus disease 19 or well known as Covid-19 has an impact on various aspects of human life in both health, economics, social, culture and even propagation in the political realm. Almost all countries in the world are moving against the Covid-19 in order to save the stability of their respective country's lives. The World Health Organization (WHO) has even issued a statement Covid-19 as a world pandemic and asks people of the world to collaborate globally in completing this pandemic (www.who.int).

In Indonesia, patients who were infected with Covid-19 suffered sharp fluctuations. According to data from the Ministry of Health, the number of positive patients Covid-19 reached the number 20,162 with details of 4,838 patients healed and 1,278 patients died (www.kemkes.go.id). To reduce the improvement of positive patients Covid-19 the Government of the Republic of Indonesia has sought to implement several health protocols that must be obligated to all Indonesians. Starting from the use of soap when washing hands, using hand sanitizer, wearing masks when traveling, spraying disinfectant in citizens' environment, and social distancing until large-scale social restrictions (PSBB) in some areas of Indonesia.

Behind the government policy there are certain problems that arise. The problems are in the economic field, the employee housing, terminating of employment, declining Micro, Small and Medium Enterprises (MSME) income and weakening rupiah currency against the 
dollar. Social issues include the rise of protests committed by communities related to the distribution of social assistance that is less equitable in some provinces in Indonesia. The health field has also suffered problems due to lack of medical devices and the shortage of medic is not comparable to the more patients who are exposed to Covid19. In the field of education, many schools are temporarily canceled so students are required to study at home. There are also interesting that can be researched related to Indonesian women and pandemic Covid-19. Precisely, because of the recommendations of the Government of the Republic of Indonesia to the community stay at home, study at home until Work from Home (WFH) was found to be able to produce and perpetuate gender-based violence in women, especially domestic violence (KDRT) (www.bbc.com). Even since the emergence of pandemic Covid19 in the Republic of Indonesia, which is March 2-April 25, 2010 the Ministry of Women Empowerment and Child Protection (PPPA) recorded a report of 275 cases of violence against adult women (www.kemenpppa.go.id) the newly reported. The home of being the safest place to stay with your own family, pandemic Covid-19 struck, turned out to trigger a new case of violence in Indonesian women. According to a journal (Stylianou, 2018) that women who have experienced violence either physically, sexually, psychologically, sociallypsychologically or vulnerable economies have severe depression. Of course, this is dangerous and can effect not good for the future of women victims of violence. Domestic Violence (KDRT) in addition to causing physical and mental health problems also found in some cases resulted in women dying or loss of life (Idris, Rasip, \& Khalid, 2018).

Before the pandemic Covid-19 spread in Indonesia, it is not denied if the case of violence against women in Indonesia is still relatively high in the Southeast Asian region. The number of violence against women in Indonesia cannot be lowered. Referring to the Domestic Violence Elimination Act law (UU PKDRT) No. 23, 2014 article 1 paragraph 1: "Every deed of person (especially women and children) resulting in physical, sexual, psychological, and or domestic affliction of the household including threats to perform acts, coercion or deprivation of freedom against the law of the household. "Women and girls often 
experience serious violence such as domestic violence, rape and even forced marriage (Caragnano, 2018).

Women's violence includes physical violence, psychic (mental), sexual violence to economic violence (Hanum, 2018). The rise of violence against women year by year, many speculations appear in the community when the case of violence in the Republic of Indonesia will expire. In fact, many women were able to occupy parliamentary seats and reveal the racial issues to raise the dignity of women. Apparently, there is a pattern of dependence and limitation of women's access to education, economic resources and other sources of authority gives the construction of a violent (Rohmaniyah, 2019). From the dependence and limitations of the woman finally made a lasting violence for women in Indonesia. Not only that, sometimes customary legal treatment and the habit of rules in certain areas affect the life of Indonesian women, including a case of violence for women. The Indonesian government has tried to make various efforts so that the violence against women throughout the Indonesian region decreases. Both through agencies are sheltered by their own government as well as institutions such as Non-Government Organization (NGO).

According to the release statement of National Commission on Violence Against Women (KOMNAS Perempuan) social policy from the Government of the Republic of Indonesia to the citizens during the pandemic, makes the "burden" of women in the house increased and can even be said multilayered. Besides having to work on domestic business such as cleaning the house, washing clothes, and cooking food, women should also help their children study at home because the educational institution during pandemic Covid-19 was temporarily closed until pandemic ended. Since the first, woman actually have double burden. In the book (Dzuhayatin, 2015) the role of women in the family and public roles can be practiced by women in a well-appointed origin of mutual support. But when certain situations occur, women's doubles can turn into weights and cause women to experience violence. There is a specific situation that raises emotional distress and makes women a victim of violence by his own partner (Edwards \& Dardis, 2016). The Covid-19 pandemic situation is one of them, where women can experience violence by their husband or other family members. Other than women are easily 
infected, women are also very vulnerable to getting domestic violence done by their own family environment.

It is more worrying when women victims of domestic violence do not report to government agencies or social organizations engaged in women violence or even police. Research from (Douglas, 2019) explains that fears and embarrassment or the sake of covering "disgrace" is a factor in the cause of the women's victims of violence reluctant to report. It is very worrying if the victims do not dare to report to the competent party to handle the domestic violence, then the woman will surely get the violence again. The recurrence of violence suffered by women in Indonesia increased the rate of violence against women. Although the pandemic Covid-19 is still attack violently, violence against women should not occur and it is supposed that the home is the safest place for women. Women are humans who have independence over their lives, not subjects of violence by men. Women should also speak up when they experience or know of violent events against women. Therefore, there needs to be collaboration and ongoing synergy between the government, the social organization of the women, and the whole community. It is starting from the lowest level to the highest level, the central government. They should help to suppress the number of violent cases against women in Indonesia. It is important for all elements to be actively escorting and supervising any problematic in the women world. Moreover, during the Covid-19 pandemic, not everyone is free to travel because of the Government's health protocol that must be obeyed by the public.

Based on the record of violence against women of the National Commission for Women (Komnas Perempuan) of Indonesia, there are three provinces that have the highest female hardness figures in Indonesia namely West-Java province, Central Java province and Jakarta provincial capital DKI (www.komnasperempuan.go.id). In 2019, Central Java province was able to lower the number of cases of violence against women from ranking one to two. If in 2018 figures of violence against women in Central Java province reached 2,913 cases, then the year 2019 fell to 2,525 cases. The decline is certainly a draw with hard work and smart work of women organizations in Central Java both government agencies and NGOS to suppress the rate of violence against women in 35 districts in Central Java province. 
During the pandemic of the Covid-19 still struck Indonesia, the provincial government of Central Java should not be a careless that resulted in increased cases of women and children. So the achievement of decreased cases of violence in 2019 can be maintained. It needs solid and strong cooperation between government agencies in the areas of women such as the Women Empowerment Office, Child protection, population control and family planning (DP3AP2KB) provincial level to the city district level, Legal Aid Institute (LBH), and women organizations that actively voice the issue of stop violence against women. The Covid-19 pandemic period makes counseling and Reporting services for cases of female violence not to be reported quickly. It is not only citizens who should anticipate this, but also a lot of parties. One of the women organizations in Central Java province that is active in the problem of various cases of violence for women and children is Legal Resources Center for gender Justice and Human Rights (LRC KJHAM). Women have since been in organization for the change, income, support and solidarity of fellow women (Mosse, 2004). LRC KJHAM was formed since the end of 1998 in Semarang. LRC KJHAM remains active in opening and providing complaints and counseling services for victims of violence during the Covid-19 pandemic while the administrators of LRC KJHAM have to work from home (WFH). It should be intertwined with intense communication between female NGOS and communities in the Covid-19 pandemic. Through the interwoven communication is expected to be able to suppress the number of cases of violence against women in the province of Central Java to the fullest.

According to Raymond S. Ross's view, communication is a process of sorting, selecting, and submitting symbols so that making listeners elicit the meaning or response of his thinking according to what the Communicator means (Mulyana, 2010). Communication can be done when there are five elements of communication. Firstly, the source, which is the initiative or the interest in initiates communication. Sources are not always individual but can also group, organization, even a state company. Secondly, message, is the process of conveying information to others into a set of verbal or non-verbal symbols. Thirdly, media is a vehicle used by the source to convey information to the recipient. Fourth, the receiver also called communicate, audience, listener, is the one who 
gets and receives a message from the source. Fifth, effect, it is something that happened to the recipient after receiving the message. For example changes in attitudes, changes in beliefs, or even behavioral changes (Changara, 2006).

From the description above, it is not easy for women organizations engaged in the social field to stay active in communicating with people in need of legal aid. From the description above, it is not easy for women organizations engaged in the social field to stay active in communicating with people in need of legal aid. LRC KJHAM requires different communication strategies to remain consistent and help voice the rights of women or the problem of Central Java women in the Covid-19 pandemic. LRC KJHAM requires different communication strategies to remain consistent and help voice the rights of women or the problem of Central Java women in the Covid-19 pandemic. Reflecting on the background above then this research is trying to find out: How is the communication strategy of women's Organizations (LRJ KJHAM) in minimizing violence against women during pandemic?

From the problem, researchers want to know and get answers regarding communication strategy as applied by women Organization (LRC KJHAM) in reducing or minimizing the occurrence of violence in the middle of Covid-19 outbreak especially in Central Java province. From the problem, researchers want to know and get answers regarding communication strategy as applied by women Organization (LRC KJHAM) in reducing or minimizing the occurrence of violence in the middle of Covid-19 outbreak especially in Central Java province. This research is expected to increase the horizon of the Special Science in Communication Science about aspects of communication strategy conducted by women organizations in suppressing the rate of violence against women in case of an outbreak in a region. In addition, it can be used as a benchmark by other researchers in the future if you want to do a research on the theme of communication science and pandemic should be different from this study.

\section{Research Method}

The method of this research was descriptive qualitative. Qualitative research is a study aimed at generating hypotheses or seeking answers to 
a problem with interpretative interpretation in accordance with the conditions of the field (Mulyana, 2010). While descriptive-qualitative is an activity to observe the social phenomena in the community in detail and scrutiny (Bajari, 2015). Research data was obtained through primary sources and secondary sources. The primary source was the result of interviews with LRC KJHAM of Semarang, while the secondary sources were obtained from journals, books and Internet sites (Pujileksono, 2015).

The data collection techniques in this study were interviews and documentation. Researcher conducted in-depth interview (indept interview) to obtain answers from an informant about the use of communication strategies in pandemic comprehensively (Bungin, 2014). The documentation was conducted by the library research method of collecting data based on journals, books, Internet sites related to this research (Pujileksono, 2015). Researcher cited international journals and national journals. For Internet sites, researcher focused on national government websites and international websites whose content was closely related to pandemic.

Researcher used sampling techniques in the form of purposive sampling, which is a technique used to determine the speaker. Researcher had specific criteria or requirements based on qualifications in accordance with this research to allow questions to be addressed to the right people. Furthermore, researcher used Miles \& Huberman analysis (Pujileksono, 2015) that there were three threads of activity that occured together and accompanied in analyzing a qualitative data, namely data reduction, data presentation and verification or withdrawal of conclusions.

\section{Results and Discussion}

The implementation of emergency response conditions by the Government of the Republic of Indonesia as a form of action prevents the dissemination of Covid-19 and protects all communities throughout the province, certainly bringing impact to the lives of the wider community. It also applies to government agencies as well as organizations that are engaged in the social-humanitarian field. The intensity of communication among the people in the pandemic period is very necessary and important to do while not being able to face directly. Cases of violence against women appearing in the Covid-19 remain to be resolved so that women 
are not always victims. When women get violent acts at home, it will cause social impact. The social impact is apathy or anti-social attitude, withdrawing from the Association of society, even the social phobia that makes victims dare not do social interaction (Rifka Annisa Women Crisis Center, 2009). Women organizations must have good communication in order to support the consumption of violence against women. There needs to be a certain system of communication strategy so that the service runs smoothly and complies with health protocols that the Government recommends.

Communication strategy is a combination of communication planning and communication management to achieve the objectives that have been established from the beginning (Effendy, 2003). Communication strategy is closely related to the management chain. Management is a way for a person, an institution, or an organization in conducting an action to achieve a specific goal by utilizing another party (Junaedi, 2014). Broadly, there are four functions of management. Those are planning function, organizing function, implementation functions that include influence and direction, and monitoring function (Junaedi, 2014).

In this study, researchers tried to use communication strategy through communication management aspects.. Eventually, researchers used Ledingham's Relationship Management Theory and Burning Relationship Management theory is a theory that focuses on organizational relationships with the public. Relationship Management theory is a theory that focuses on organizational relationships with the public. Ledingham in his journal (Waters \& Bortree, 2012) describes that the relationship of organization to the general public should be based on four matters. Those are trust, satisfaction, commitment and the last is control. Commitment and the latter is control. Ledingham and Burning also argue that the essence of the theory is to build mutually beneficial relationships with the realization of the dream to be achieved together. Based on Relationship Management Theory's point of view, it has been duly Legal Resources Center for gender Justice and Human Rights (LRC KJHAM) Creating a safe environment and maintaining the intensity of communication with the community, especially women and who are 
experiencing violence in order to reach common goals. Relationship management theory is divided into two sections such as the table below:

Table 1. Relationship Management Theory

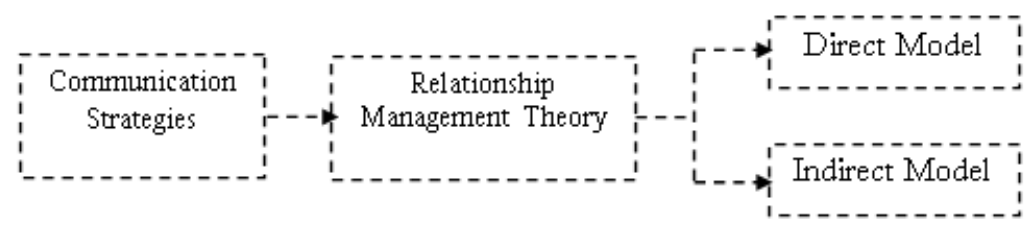

\section{Relationship Management Theory: Direct Relationship Model}

Relationship management theory occurs directly when the organization/institution can communicate face-to-face directly with the audience. In any situation and era, communication and information is a basic necessity of individual or organization in accordance with the availability of communication facilities (Broto, 2014). Although the outbreak of Covid-19 entered Indonesia, the organization that concentrates on the social field of society should be professional in controlling all sorts of problematic in the community. Including LRC KJHAM in Central Java province, it continues to open direct-to-face pathways to maintain public trust and to prove its commitment to help women in districts/cities who are gaining violent treatment or to see directly the incidence of violence against women during the Covid-19. As the following exposure to LRC KJHAM Chairman:

"It is true that the protocol according to the Government of the Republic of Indonesia that the community is obliged to work from home (WFH), study at home and also stay at home. But for us, the caretaker and all members of LRC KJHAM still imposed the picket schedule in turns. Not all admins and members are in the same room when carrying out pickets. Because we are keeping the distance, then only one or two people are on guard and are in a different room. Their job is to listen to complaints and victims ' reports that come directly. The average victim who came in was very precarious and had to do face to face. In order to maintain the health of the Board as well as members who are in a picket, they must wear masks and others to protect the body from the Covid-19. The Office also provides soap and accessories such as a hand sanitizer for guests or complainants."

Santi, chairman of LRC KJHAM, said that the relationship between the female organization and the surrounding community still 
operates in a direct way or through front-face. But the difference is that during the pandemic Covid-19, face-in sessions are directly restricted, not all reporters can be served as a whole. The community will be served directly by LRC KJHAM If the circumstances do require the meeting or the persistence is urgent, precarious and indeed harm the state of the reporter. For people who are not in the condition of "dangerous" can't or in other words are not encouraged to do face-to-face directly for the sake of maintaining health.

\section{Relationship Management Theory: Indirect Relationship Model}

Indirect relationship management theory model is management that utilizes a particular medium. The media is a tool that can be used to communicate without having to face up front, namely social media. In the era of industrial freedom, the media ruled by formulating conversations of many people despite being separated by distance (Arief \& Utomo, 2015). The current application of the use of social media platforms is done by many organizations. Social media is the most desirable medium in order to promote an organization or limit communicating with the audience.

The implementation of social distancing by the Government of the Republic of Indonesia makes social media benefits increased. It is also done by LRJ KJHAM in order to keep track and control cases of violence against women in all districts of the city in the province of Central Java, such as the results of the following interview conversations:

"We held a campaign on the Stop violence against women and children on social media platforms that LRC KJHAM had. We also utilize the social media for all communities to complain to social media admins when viewing, knowing, hearing or experiencing a violent treatment. There are four active social media in the LRC KJHAM namely Facebook, Instagram, Twitter, You tube and Path. "

In the research of Michael Haenlin and Andreas Kaplan (Cahyono, 2016) explained that social media is as an Internet-based application built on the basis of ideology and Web 2.0 technology that is very possible creation and exchange of user generated content. In the era of such massive technology and information, the dissemination of information in the general audience is very fast. The community is free to consume 
which social media will be used according to their will, including the use of social media by the organization. The use of social media for an organization can't be as haphazard as using private social media, the name of the institution becomes a benchmark so that social media does not provide information with poor quality or can also hoax. The existence of five social media accounts managed intensely by LRC KJHAM during the period of pandemic Covid-19 is expected to maintain an organic relationship with the community. The presence of social media in pandemic time is necessary because it is quite effective. Through the virtual world, it can open up opportunities for anyone to exchange information, including between the LRC KJHAM and the wider community.

Researchers will slightly dissect the five accounts used by LRC KJHAM. Facebook is a social media that allows account owners to post photos and create long stories about the photos. In addition, account owners can also upload videos. Almost the same as Facebook, Instagram can also be used by account owners to view photos or videos with little captions, not being able to write as much on Facebook. While Twitter the content is shorter, dense and clear. The Path also displays photos with captions that are not much. Different from the four social media platforms before, youtube presents a long-lasting video view. These five social media platforms are used as tools by LRC KJHAM as a weapon in controlling the case of violence against women at pandemic.

In each social media owned by LRC KJHAM were installed pamphlets that invite people to dare to report violence against women. LRC KJHAM saw that the stop movement of violence against women in pandemic via social media platforms could be a way to prevent and minimize cases of violence against women, particularly in the districts and cities of Central Java. Social media utilization is deemed necessary in order that the relationship between the organization and audience is closer even though it cannot be directly face-to-face. The social media platform of LRC KJHAM is also used to provide announcements about various discussions via online media organized by LRC KJHAM. The continuous use of social media platforms with the case of violence against women and the Covid-19 is quite important considering that pandemic Covid-19 is still uncertain when it will expire. 


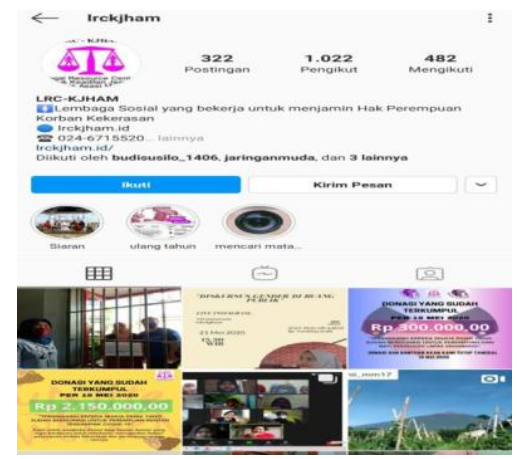

Picture 1. Instagram Account of LRC KJHAM

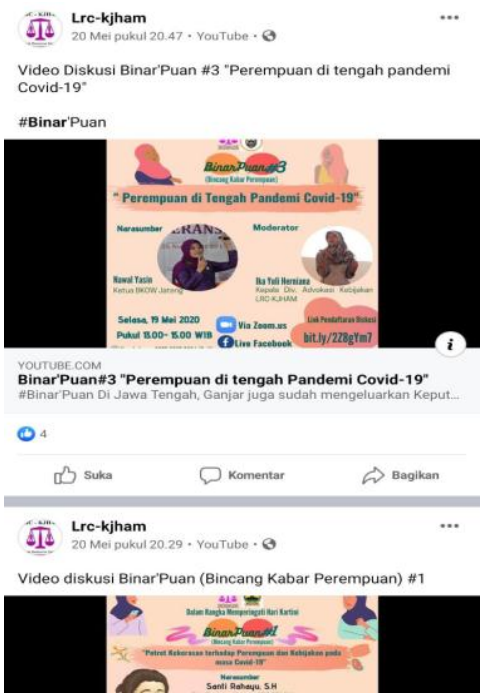

Picture 2. Facebook Account of LRC KJHAM $\leftarrow$ LRC KJHAM

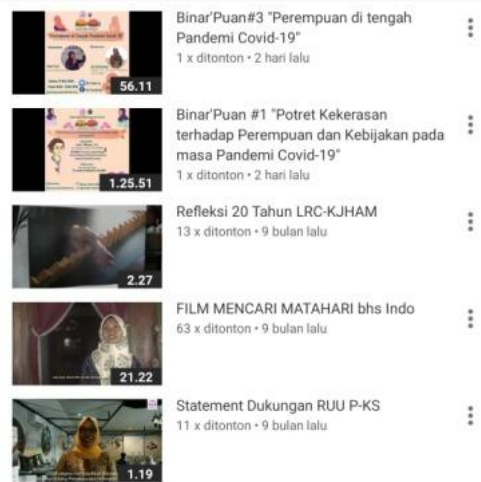

Picture 3. Youtube Account of LRC KJHAM 
Not only utilizing the five social media that has been described above, LRC KJHAM also provides services and receives complaints reported via telephone. When asked about it, Santi gave a response as below:

"Office phone service as usual starts at 08.30-16.30. But the complainants can also call the number of the administrators and members of LRC KJHAM. We are as an organization that is engaged in social community trying to give the best contribution to the complainants. For personal numbers, each LRC KJHAM Manager can be contacted for 24 hours. There are some victims who once complained and kept our numbers, we also ask them to provide our number when there are neighbors, friends, or relatives who need counseling services during pandemic Covid-19."

The managers of LRC KJHAM also provide services to victims of domestic violence, victims of violence in courtship or trafficking victims. In addition, during the period of pandemic, the caretaker kept counseling for the victims for free without paying. Counseling and healing if not too severe can be through a cell phone. Victims can directly contact LRC KJHAM Manager in order to get a consultation schedule. LRC KJHAM continues to open a consulting service so that the victims can recover from bad trauma. Pandemic Covid-19 is not a reason for the administrators of LRC KJHAM to not be able to participate in preventing violence against women.

In addition to using social media, LRC KJHAM also held virtual discussions through the Zoom app. Zoom is an application that can accommodate many people in a single online discussion. Speakers and audiences can face each other via virtual. This is in accordance with LRC KJHAM's management program, which is organizing a one-month discussion to bring closer and introduce LRC KJHAM to the public. In each of the discussions, LRC KJHAM will deliver an account of the number of violent complainants, the cause of violence against women and the motivation for their fellow women to dare to fight and act strictly for any abuse of violence by persons who are not responsible.

Unlike the discussions that had been held before, LRC KJHAM has been two months holding discussions regarding the quarterly issues through online media. The discussion theme is tailored to the conditions 
that occur today. The discussion is filled by speakers who are experts in certain fields. The LRC KJHAM discussion is open for free and applies to all public citizens. Below is the exposure of Santi to the virtual discussion of LRC KJHAM:

"We are still providing education to the general public about the dangers of violence against women and children. We always voiced these things so that the women immediately reported when they knew a case of violence against women and children. We also inform violence reporting mechanisms to make people be brave. Sometimes people want to report, but do not know how to. Virtual discussion is as one of our alternatives to give people information."

The exposure to more virtual discussions alludes to the impact of Covid-19 for women. The vulnerability of women had a high level of violence, the effect of being able to commit suicide. Additionally, LRC KJHAM also provides audience information on reporting procedures during the pandemic Covid-19. If there is no pandemic the reporter can immediately visit the office of LRC KJHAM located in the provincial capital of Central Java, Semarang. As long as pandemic is not over yet, LRC KJHAM's caretaker serves the complaints of women victims of violence over cellular phones as well as through five social media. The results of the discussion are also stored by LRC KJHAM through the delivery of content on their Youtube Channel so that people who have not had time to participate in virtual discussions can listen to the process of discussion.

In addition to maintaining good relations with the wider community, it is important for LRC KJHAM to communicate actively with organizations other than LRC KJHAM. They strengthen the network with the empowerment of women and children in all districts in Central Java province, and also cooperate with the Women and Children Protection Network (JPPA) in each village through the administrators in their respective territories. Although the distance separates, it does not mean that LRC KJHAM can immerse your-self in the middle of the Covid-19 outbreak. It is precisely a challenge for all administrators and members of LRC KJHAM to remain observant to watch for domestic violence. From the interview: 
"Without instruction by the leader, all the administrators of LRJ KJHAM have been automatically held to supervise the violence in the area in which they lived. Because, for all those who have been in the social sphere must have a high empathy and soul sensitivity that is honed when there is a problem in the community. We coordinate through WhatsApp group ".

In order to maintain the stability of the number of violence in women in Central Java, LRC KJHAM also coordinates with support group. The Support group is a group therapy that consists of women victims of violence that have been and still accompanied by LRC KJHAM (Setiawan, 2015). Coordination is done through WhatsApp group so that the manager of LRC KJHAM can immediately receive a report if there is an indication of violence against women in all districts/cities in the province of Central Java.

\section{Conclusion}

From the discussion above, it can be concluded that the communication strategy conducted by the Legal Resources Center for gender justice and human Rights in the province of Central Java can still be applied when a pandemic struck a region by implementing a relationship management theory. The use of a relationship management theory that is suitable for Relationship manager is indirectly. Because of the dominance of social media application is so high compared to the model directly.

The implementation of the Relationship management model is not immediately assessed appropriate measures for all organizations including LRC KJHAM in pandemic. In addition to maintaining health immune, the steps can also provide counseling for free via virtual and receive complaints from victims of violence through social media accounts or mobile phones. The existence of social media also makes LRC KJHAM have a wider range. If the discussion of LRC KJHAM usually can only be followed by the community in the city of Semarang and its surroundings, then through the webinar application utilization of the zoom is able to be felt by many audiences without them having to spend excess costs. LRC KJHAM hopes the relationship between LRC KJHAM with the community remains harmonious. It is important for 
government and non-governmental organizations to maximize the performance of work from home through the use of social media accounts. Managing the social media accounts of LRC KJHAM can also adjust the conditions of pandemic by lifting themes related to women in the Covid-19 pandemic by all accounts.

In this research, direct model relationship management is not so widely used. In fact, if there are complaints or counseling women victims of violence is supposed to face the counselor directly. But in a pandemic like today the model directly cannot be applied to the fullest. Health factors are prioritized by LRC KJHAM. If there is a reporter who comes to the office of LRC KJHAM in the city of Semarang, it must follow strict health protocols and only certain victims who can receive counseling directly. And it can be said dangerous when in the pandemic Covid-19 LRC KJHAM using a direct model every day. Then the communication strategy of LRC KJHAM when the pandemic Covid-19 is better realize and feature a direct model relationship management indirectly than direct models.

\section{Bibliography}

Arief, Y., Utomo, W. P. (2015). Orde Media. Jakarta: Instans Press.

Bajari, A. (2015). Metode Penelitian Komunikasi: Prosedur, Tren dan Etika. Bandung: Simbiosa Rekatama Media.

Broto, G. S. (2014). The PR: Tantangan Publik Relations di Era Keterbukaan Informasi. Jakarta: Gramedia Pustaka Utama.

Bungin, B. (2014). Penelitian Kualitatif: Komunikasi, Ekonomi, Kebijakan Publik dan Ilmu Sosial Lainnya. Jakarta: Prenada Media Group.

Cahyono, A. S. (2016). "Pengaruh Media Sosial Terhadap Perubahan Sosial Masyarakat di Indonesia”. Jurnal Unita. Vol 140-157.

Caragnano, R. (2018). "Violence Againts Women \& Domestic Violence:

General Framework and Overview of The Convention". Athens Journal of Law , 51-66.

Changara, H. (2006). Pengantar Ilmu Komunikasi. Jakarta: Raja Grafindo Persada.

Douglas, H. (2019). "Policing Domestic and Family Violance". International Journal for Crime, Justice and Social Democrazy, 31-49.

Dzuhayatin, S. R. (2015). Rezim Gender Muhammadiyah: Kontestasi Gender, Identitas dan Eksistensi. Yogyakarta: Pustaka Pelajar. 
Edwards, K. M., \& Dardis, C. M. (2016). Disclosure Recipients Social Reaction To Victims Disclosures On Intimate Partner. Journal of Interpersonal Violance. 1-17.

Effendy, O. U. (2003). Ilmu, Teori dan Filsafat Komunikasi. Bandung: PT Citra Aditya Bakti.

Hanum, F. (2018). Kajian Dan Dinamika Gender. Malang: Intrans Publishing.

Idris, S. A., Rasip, K. A., \& Khalid, R. K. (2018). Causes and Effect Domestic Violance: A Conceptual Model On The Performance At Work. 4th Putrajaya International Conference On Children, Women, Elderly and People with Disabilities (pp. 84-94). Malaysia: Research Gate.

Junaedi, F. (2014). Manajemen Media Massa. Yogyakarta: Litera.

Mosse, C. J. (2004). Gender dan Pembangunan. Yogyakarta: Pustaka Pelajar.

Mulyana, D. (2010). Ilmu Komunikasi Suatu Pengantar. Bandung: PT Remaja Rosdakarya.

Mulyana, D. (2010). Metodologi Penelitian Kualitatif: Paradigma Baru Ilmu Komunikasi dan Ilmu Sosial Lainnya. Bandung: PT Remaja Rosdakarya.

Pujileksono, S. (2015). Metode Penelitian Kualitatif. Malang: Intrans Publishing.

Rifka Annisa Women Crisis Center. (2009). Wajah Kekerasan: Analisis Data Kasusu Kekerasan Terhadap Perempuan di Rifka Annisa. Yogyakarta: Rifka Annisa WCC.

Rohmaniyah, I. (2019). Gender \& Seksualitas Perempuan Dalam Pertarungan Wacana Tafsir. Yogyakarta: Larassukma.

Setiawan, Y. B. (2015). Solusi Support Group. Semarang: Semarang University Press.

Stylianou, A. (2018). Economic Abuse Experience and Depressive Symptoms Among Victims of Intimate Partner Violance. Journal of Family Violance, 381-392.

Waters, R. D., \& Bortree, D. S. (2012). Advancing Relationship Management Theory: Mapping The Continuum of Relationship Types. Public Relation Review, 123-127.

www.kemenke.go.id retrieved on Thursday, 21 of May 2020 at 18.06.

www.who.int retrieved on Tuesday, 19 of May 2020 at 14.34.

www.bbc.com retrieved on Tuesday, 19 of May 2020 at 15.25.

www.komnasperempuan.go.id retrieved on Tuesday, 19 of May 2020 at 15.56 .

www.kemenpppa.go.id retrieved on Thursday, 21 of May 2020 at 19.27. 